\title{
National Health Systems and the pandemic by COVID-19: actions to cope with Brazil and Italy
}

I ${ }^{1}$ Rayssa Horacio Lopes, ${ }^{2}$ Janmilli da Costa Dantas, ${ }^{3}$ Richardson Augusto Rosendo da Silva, ${ }^{4}$ Severina Alice da Costa Uchoa I

Abstract: The objective was to identify the actions developed by the health systems of Brazil and Italy to face the pandemic caused by COVID19. This is an integrative literature review in the Web of Science, Scopus, Pubmed and Virtual Health Library databases, with the addition of the snowball technique, in July 2020. After collection, 48 publications constituted the sample. The actions of the health systems of the two countries to face the pandemic were grouped into the categories: Adequacy of the legal norms of the health system; Expansion and strengthening of the health system; Use of Information and Communication Technologies; Encouraging individual and collective measures to face the pandemic; and Limitations and challenges in facing the pandemic. The measures adopted are influenced by the political, economic and social contexts. There was a reorganization of the hospital network in both countries, but weaknesses are identified in the preventive actions developed by Primary Health Care, with a predominance of the biomedical model. Telemedicine stood out in this scenario and could last in the post-pandemic. The summary of actions will subsidize the confrontation of other pandemics that, eventually, the health systems of these and other countries may encounter.

> Keywords: Coronavirus infections; Pandemics; Health Systems; Italy; Brazil.

\author{
${ }^{1}$ Federal University of Rio Grande \\ do Norte. Natal-RN, Brazil \\ (rayssahlt@hotmail.com) \\ ORCID: 0000-0001-7041-4792 \\ ${ }^{2}$ Federal University of Rio Grande \\ do Norte. Natal-RN, Brazil \\ (janmilli@yahoo.com.br). \\ ORCID: 0000-0001-5429-6108 \\ ${ }^{3}$ Federal University of Rio \\ Grande do Norte. Natal-RN, \\ Brazil (rirosendo@yahoo.com.br) \\ ORCID: 0000-0001-6290-9365 \\ ${ }^{4}$ Federal University of Rio Grande \\ do Norte. Natal-RN, Brazil \\ (alicedacostauchoa@gmail.com) \\ ORCID: 0000-0002-2531-9937
}

Received in: 11/08/2020 Approved in: 15/03/2021 Revised in: 13/10/2021 


\section{Introduction}

The viral disease called COVID-19 was first identified in Wuhan, China, in December 2019. The etiological agent is a new coronavirus, with high transmissibility, and a portion of those infected may evolve with severe respiratory distress (FRATER et al. 2020). New and cases have emerged rapidly in other Asian countries, spreading to Europe and other continents, which led the World Health Organization (WHO) to enact a Public Health Emergency of International Importance on January 30, 2020, and a pandemic on March 11, 2020 (WORLD HEALTH ORGANIZATION, 2020a, 2020b).

In Europe, Italy began to gain prominence for the considerable number of cases presented and mortality from the disease. Three cases were identified in late January and all individuals involved had recently traveled to China. The first case with no history of exposure to the outside was diagnosed in Lombardy on February 20 (ONDER; REZZA; BRUSAFERRO, 2020). The country has become important worldwide because of the number of cases and deaths it has started to present. On July 13, 2020, the number of confirmed cases for COVID-19 was already 243,230 and the number of deaths reached 34,967 (WORLDOMETER, 2020).

The National Health System of Italy (INHS) provides universal coverage, financed by regional taxation. It's been a process of change in the last few years. The regions gained autonomy, promoting the private sector and reducing public hospitals. The System has suffered cuts in its financial resources and lack of replacement of human resources. There is a strong centralization of care in hospitals, weakening territorial health (BUCCIARDINI et al., 2020). Even in primary health care, there is a production of a clinic that is focused on the intervention of the biomedical model (MARTINO et al., 2015).

In Latin America, Brazil recorded the first case on February 25, 2020, in the city of São Paulo, a man who had returned from Lombardy, Italy (RODRIGUEZMORALES et al., 2020). Since then, the epidemic has expanded in Brazil, making it one of the countries to reach the highest numbers of COVID-19 infected in the world. As of July 13, 2020, 1,884,967 cases and 72,833 deaths had been confirmed in all federal units (BRASIL, 2020a). It is notepoint that the country has not adopted broad testing strategies in the population, which leads us to think of a high number of underreporting of cases and deaths due to COVID-19. 
Brazil also has a public health system, the Unified Health System (SUS), guided by the principles of universality, integrality and equity. Primary Health Care is consolidated by the Family Health Strategy teams, capable of providing comprehensive care and developing health promotion, constituting the main gateway of the user in the SUS and axis of coordination of care and ordering of the Health Care Network (HCN). The SUS has been experiencing cuts in its financing, weaknesses in the regulation exercised by the Ministry of Health, hindering the decentralization process in the municipalities (MOROSINI; FONSECA; LIMA, 2018).

The identification of the actions developed by the health system of these countries becomes of significant importance for reflection on the strategies implemented and obstacles of health systems, enabling us to direct other countries to paths of containment of COVID-19. Comparing health systems between two countries, with different social and economic conditions, with the characteristic of public health systems, becomes important to understand lessons learned. It is relevant for Public Health regarding the promotion of practices of organization of public health systems in the face of a global health emergency and the formulation of new public health policies.

The study aimed to identify the actions developed by health systems in Brazil and Italy to cope with the pandemic by COVID19.

\section{Methods}

This is an integrative review of the literature, a research method that analyzes the published knowledge about a given theme, enabling its summation, expanding the understanding of the object of study of interest (WHITTEMORE; KNAFL, 2005; SOUZA; SILVA; CARVALHO, 2010).

The research was guided by the following stages, adapted from the relevant methodological framework of Whittemore and Knafl (2005) and Souza; Silva e Carvalho (2010): formulation of the problem and research questions; preparation and approval of the research protocol; data collection; analysis and interpretation of the data; presentation of the results of the review.

Thus, the review sought to answer the following question: What are the actions developed by health systems in Brazil and Italy to cope with the pandemic by COVID-19? 
As a search strategy, the use of the Brazilian database: Virtual Health Library (VHL) was defined, using the crossing of Descriptors in Health Sciences (DECS) and, in the international literature databases, Web of Science, Scopus, PubMed, the Medical Subject Heading (MeSH) was used.

In all the searches at the bases, conducted by two independent researchers and simultaneously, in July 2020, Boolean operators 'AND' or 'OR', and, when available, the country filters (Brazil and Italy) were used; language (Portuguese, English, Italian); period (2019 to 2020), aiming to portray exactly the pandemic currently experienced.

The search strategy was configured as shown in Board 1.

Board 1. Strategy for crossing The DeCS and MeSH according to the database.

\begin{tabular}{|l|l|}
\hline DATABASE & DECS AND MESH CROSSING STRATEGY \\
\hline $\begin{array}{l}\text { SCOPUS } \\
\text { Collection: 7/6/20 }\end{array}$ & $\begin{array}{l}\text { (TITLE-ABS-KEY (public AND health AND systems AND research) AND } \\
\text { TITLE-ABS-KEY (pandemics) AND TITLE-ABS-KEY ("Coronavirus } \\
\text { infections") OR TITLE-ABS-KEY (Coronavirus)) }\end{array}$ \\
\hline $\begin{array}{l}\text { VHL } \\
\text { Collection: 7/6/20 }\end{array}$ & $\begin{array}{l}\text { (tw:("health systems")) AND (tw:(pandemic)) AND (tw:("Coronavirus } \\
\text { infections")) OR (tw:(Coronavirus)) }\end{array}$ \\
\hline $\begin{array}{l}\text { PUBMED } \\
\text { Collection: 7/7/20 }\end{array}$ & $\begin{array}{l}\text { ("coronavirus"[MeSH Major Topic] OR "coronavirus infections"[MeSH Major } \\
\text { Topic]) AND "pandemics"[MeSH Major Topic] }\end{array}$ \\
\hline $\begin{array}{l}\text { WEB OF SCIENCE } \\
\text { Collection: 7/7/20 }\end{array}$ & TS=("Pandemics" AND “Coronavirus" OR "Coronavirus infections") \\
\hline
\end{tabular}

Source: research protocol.

The inclusion criteria established were: publications (research articles, experience reports, books, manuals, bulletins, academic papers, legal regulations and communications of health services) with access to the full text through the CAPES Journal Portal, through registration in the Federated Academic Community of the Federal University of Rio Grande do Norte; in the Portuguese, English and Italian; 2019-2020 period; to portray the experiences of health systems in Brazil and Italy in the confrontation of COVID-19. Duplicate studies were excluded, which were inserted in the first search portal; review articles exclusively; publications of nonscientific newspapers and journals. 
Additionally, to expand the corpus of analysis, we used the snowball sampling technique, in which, based on the references of the publications found, we sought to include other publications, especially dealing with the Italian reality, since the search in the above-mentioned databases presented a significant difference between the amount of material related to Brazilian and Italian strategies. For this methodological phase, the same inclusion and exclusion criteria defined above were adopted.

Data were collected for analysis through the preparation of a Microsoft Excel 2010 spreadsheet, with the following indicators: title, month/year of publication, authors, type of material, database in which it was found, language, country to which the publication and action of coping with the pandemic by COVID-19 presented refers. The standardization of these indicators was included in the research protocol and data extraction was also done by two researchers independently.

The data were analyzed from simple descriptive statistics with presentation of $\mathrm{n}$ and \%, being made available through collection diagram, tables, in addition to the creation of thematic categories and discussed in the light of the relevant scientific literature.

This research, because it is a literature review, is exempted from the ethical assessment for not using human beings, or their information, in accordance with the Resolution of the National Health Council (NHC) n. 466 of 2012 (NATIONAL HEALTH COUNCIL, 2013).

\section{Results}

The research resulted in the inclusion of 48 publications to make up the sample, after all phases performed and application of the established criteria, as highlighted in the diagram in Figure 1. 
Figure 1. Publications selection diagram.
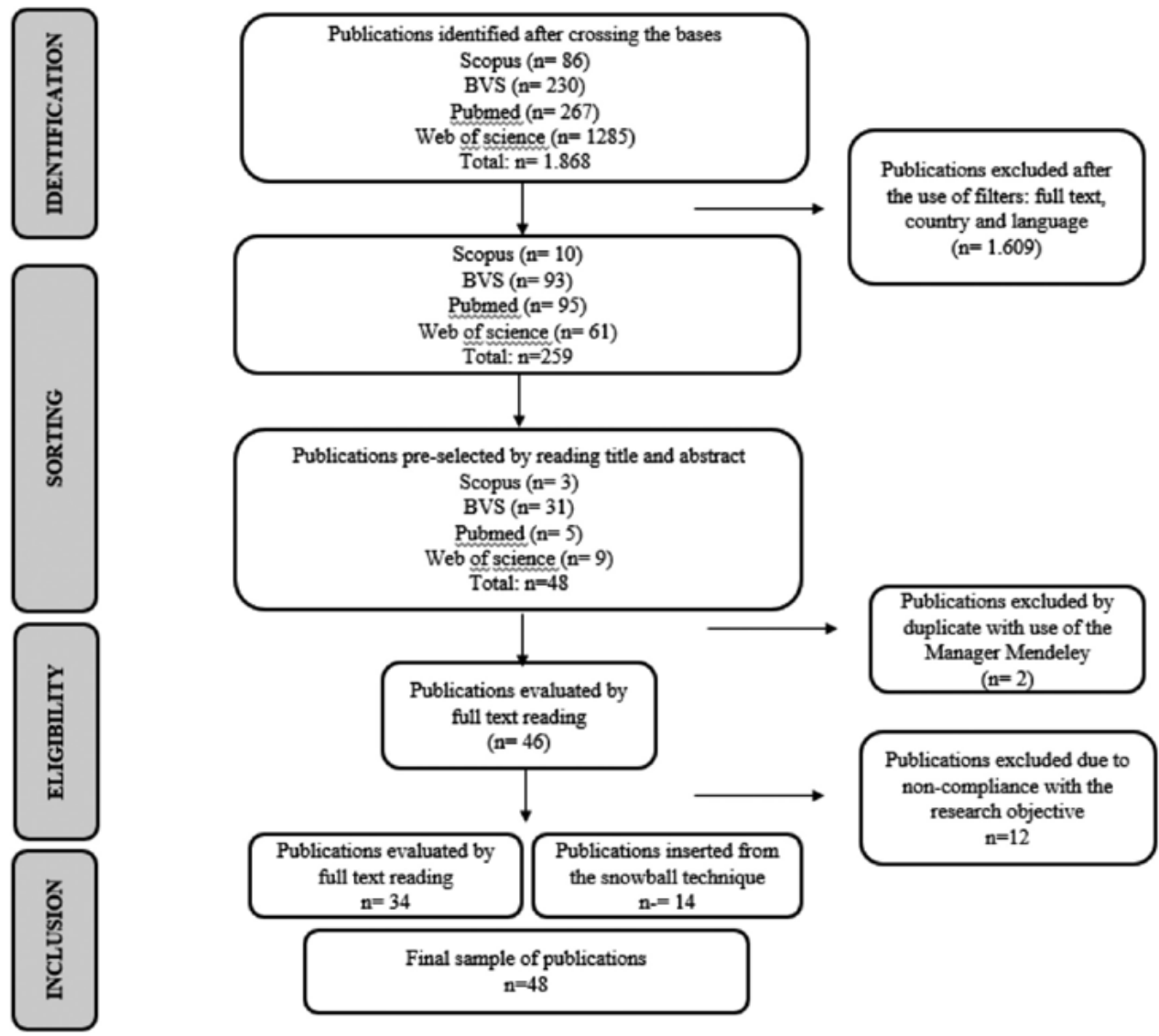

Source: search data.

The publications found in the review and from the snowball technique were mostly authored by the Brazilian health system (47.9\%), through its various constituent bodies, such as the Ministry of Health $(\mathrm{MOH})$, National Health Surveillance Agency (ANVISA), secretariats of specific areas and National Council of Health Secretaries (NCHS), in addition to publications by the President of the Republic, in the first half of 2020, as shown in Board 2. 
Board 2. Characterization of publications regarding the database in which they were found, title, authors and month/year of publication.

\begin{tabular}{|c|c|c|c|}
\hline Database & Title & Authors & $\begin{array}{c}\text { Month/ } \\
\text { year }\end{array}$ \\
\hline \multirow{2}{*}{$\begin{array}{l}\tilde{O} \\
\stackrel{0}{0}\end{array}$} & $\begin{array}{l}\text { The comparative politics of COVID-19: The need to } \\
\text { understand government responses. }\end{array}$ & Greer, S. L., et al. & $06 / 20$ \\
\hline & How Brazil can stop COVID-19 & Oliveira, W. K., et al. & $05 / 20$ \\
\hline \multirow{17}{*}{$\sum_{\infty}^{\infty}$} & $\begin{array}{l}\text { Bed Qualification Monitoring Panel SRAG/ICU } \\
\text { Covid-19 }\end{array}$ & NCHS & $06 / 20$ \\
\hline & Ministerial Office (MO) Ordinance n. 1444 & $\mathrm{MOH}$ (substitute min.) & $05 / 20$ \\
\hline & Ministerial Office (MO) Ordinance n. 1445 & $\mathrm{MOH}$ (substitute min.) & $05 / 20$ \\
\hline & $\begin{array}{l}\text { Ordinance of the Department of Specialized Health } \\
\text { Care (DSHC) n. } 245\end{array}$ & $\mathrm{MOH}(\mathrm{SAES})$ & $03 / 20$ \\
\hline & Ministerial Office (MO) Ordinance n. 1514 & $\mathrm{MOH}$ (acting min.) & $06 / 20$ \\
\hline & Ministerial Office (MO) Ordinance n. 1521 & $\mathrm{MOH}$ (acting min.) & $06 / 20$ \\
\hline & $\begin{array}{l}\text { Ordinance of the Department of Specialized Health } \\
\text { Care (DSHC) n. } 510\end{array}$ & $\mathrm{MOH}(\mathrm{SAES})$ & $06 / 20$ \\
\hline & $\begin{array}{l}\text { Resolution of the Collegiate Board of Directors } \\
\text { (RCD) Anvisa n. } 395\end{array}$ & ANVISA & $06 / 20$ \\
\hline & Ministerial Office (GO) Ordinance n. 1565 & $\mathrm{MOH}$ (acting min.) & $06 / 20$ \\
\hline & Ministerial Office (GO) Ordinance n. 1579 & $\mathrm{MOH}$ (acting min.) & $06 / 20$ \\
\hline & Complementary Federal Law n. 173 & $\begin{array}{l}\text { President of the } \\
\text { Republic }\end{array}$ & $05 / 20$ \\
\hline & Federal Law n. 13,995 & $\begin{array}{l}\text { President of the } \\
\text { Republic }\end{array}$ & $05 / 20$ \\
\hline & $\begin{array}{l}\text { Resolution of the Collegiate Board of Directors } \\
\text { (RCD) Anvisa n. } 371\end{array}$ & ANVISA & $04 / 20$ \\
\hline & Ministerial Office (GO) Ordinance n. 827 & $\mathrm{MOH}$ & $04 / 20$ \\
\hline & $\begin{array}{l}\text { Ministerial Office (MO) Ordinance n. 758, of April } \\
9,2020\end{array}$ & $\mathrm{MOH}$ & $04 / 20$ \\
\hline & $\begin{array}{l}\text { Ordinance of the Department of Specialized Health } \\
\text { Care (DSHC) n. } 237\end{array}$ & $\mathrm{MOH}(\mathrm{SAES})$ & $03 / 20$ \\
\hline & Ministerial Office (GO) Ordinance n. 430 & $\mathrm{MOH}$ & $03 / 20$ \\
\hline
\end{tabular}




\begin{tabular}{|c|c|c|c|}
\hline Database & Title & Authors & $\begin{array}{c}\text { Month/ } \\
\text { year }\end{array}$ \\
\hline \multirow{9}{*}{$\sum$} & Ministerial Office (GO) Ordinance n. 545 & $\mathrm{MOH}$ & $03 / 20$ \\
\hline & Ministerial Office (GO) Ordinance n. 580 & $\mathrm{MOH}$ & $03 / 20$ \\
\hline & Ministerial Office (GO) Ordinance n. 639 & $\mathrm{MOH}$ & $03 / 20$ \\
\hline & $\begin{array}{l}\text { Ordinance of the Special Secretariat for Indigenous } \\
\text { Health (SSIH) n. } 16\end{array}$ & $\mathrm{MOH}(\mathrm{SESAI})$ & $03 / 20$ \\
\hline & $\begin{array}{l}\text { Resolution of the Collegiate Board of Directors } \\
\text { (RCD) Anvisa n. } 377\end{array}$ & ANVISA & $04 / 20$ \\
\hline & $\begin{array}{l}\text { Resolution of the Collegiate Board of Directors } \\
\text { (RCD) Anvisa n. } 381\end{array}$ & ANVISA & $05 / 20$ \\
\hline & $\begin{array}{l}\text { Comparing South Korea and Italy's healthcare } \\
\text { systems and initiatives to combat COVID-19 }\end{array}$ & Palaniappan, A. et al. & $04 / 20$ \\
\hline & $\begin{array}{l}\text { Challenges and opportunities for telehealth in times } \\
\text { of the COVID-19 pandemic: a reflection on spaces } \\
\text { and initiatives in the Brazilian context }\end{array}$ & Caetano, R., et al. & $06 / 20$ \\
\hline & $\begin{array}{l}\text { The role of primary care in combating Covid-19: } \\
\text { impact on public health and future perspectives }\end{array}$ & Farias, L.A.B. G., et al. & $05 / 20$ \\
\hline \multirow{2}{*}{$\sum_{\substack{\mid \\
\vdots}}^{\rho}$} & $\begin{array}{l}\text { COVID-19: lessons from the Italian reproductive } \\
\text { medical experience }\end{array}$ & La Marca, A., et al. & $03 / 20$ \\
\hline & $\begin{array}{l}\text { Italian public health response to the COVID-19 } \\
\text { pandemic: Case report from the field, insights and } \\
\text { challenges for the department of prevention. }\end{array}$ & Torri, E., et al. & $05 / 20$ \\
\hline \multirow{4}{*}{ 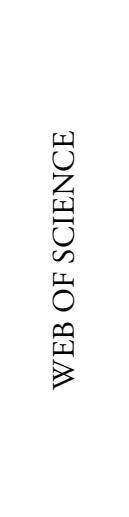 } & $\begin{array}{l}\text { COVID-19 in the state of Ceará: Behaviors and } \\
\text { beliefs in the arrival of the pandemic }\end{array}$ & Lima, D. L. F., et al. & $05 / 20$ \\
\hline & $\begin{array}{l}\text { Echocardiography in Pandemic: Front-Line } \\
\text { Perspective, Expanding Role of Ultrasound, and } \\
\text { Ethics of Resource Allocation }\end{array}$ & Drake, D. H, et al. & $04 / 20$ \\
\hline & $\begin{array}{l}\text { Response and role of palliative care during the } \\
\text { COVID-19 pandemic: A national telephone survey of } \\
\text { hospices in Italy }\end{array}$ & Costantini, $\mathrm{M}$ et al. & $04 / 20$ \\
\hline & $\begin{array}{l}\text { Use of CT and artificial intelligence in suspected or } \\
\text { COVID-19 positive patients: statement of the Italian } \\
\text { Society of Medical and Interventional Radiology }\end{array}$ & Neri, E et al. & $04 / 20$ \\
\hline
\end{tabular}

to be continued... 


\begin{tabular}{|c|c|c|c|}
\hline Database & Title & Authors & $\begin{array}{c}\text { Month/ } \\
\text { year }\end{array}$ \\
\hline \multirow{14}{*}{ 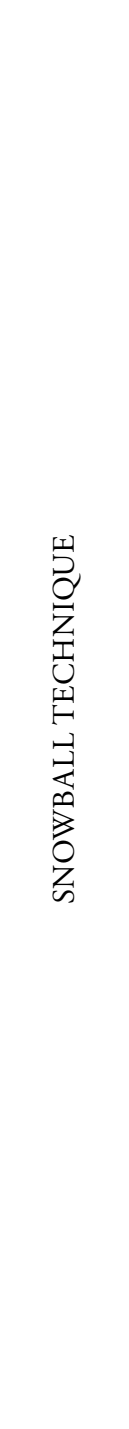 } & Nota del Centro Nazionale Sangue no 3021A. & $\mathrm{MOH}$ (CNS) & $01 / 20$ \\
\hline & Decreto del Consiglio dei Ministri n. 26 & $\begin{array}{l}\text { Presidente del } \\
\text { Consiglio }\end{array}$ & $01 / 20$ \\
\hline & $\begin{array}{l}\text { Circolare (Prot. } 429 \text { CNT 2020) del Centro } \\
\text { Nazionale Trapianti }\end{array}$ & $\mathrm{MOH}(\mathrm{CNT})$ & $02 / 20$ \\
\hline & Decreto del Consiglio dei Ministri no 45 & $\begin{array}{l}\text { Presidente del } \\
\text { Consiglio }\end{array}$ & $02 / 20$ \\
\hline & Decreto del Consiglio dei Ministri no 59 & $\begin{array}{l}\text { Presidente del } \\
\text { Consiglio }\end{array}$ & $03 / 20$ \\
\hline & Decreto del Consiglio dei Ministri no 76 & $\begin{array}{l}\text { Presidente del } \\
\text { Consiglio }\end{array}$ & $03 / 20$ \\
\hline & Decreto del Consiglio dei Ministri no 97 & $\begin{array}{l}\text { Presidente del } \\
\text { Consiglio }\end{array}$ & $04 / 20$ \\
\hline & $\begin{array}{l}\text { What other countries can learn from Italy during the } \\
\text { COVID-19 Pandemic. }\end{array}$ & $\begin{array}{l}\text { Boccia, S.; Ricciardi, } \\
\text { W.; Ioannidis, J.P.A }\end{array}$ & $04 / 20$ \\
\hline & Lessons from Italy's response to coronavirus. & $\begin{array}{l}\text { Pisano, G.P.; Sadun, } \\
\text { R.; Zanini, M. }\end{array}$ & $03 / 20$ \\
\hline & $\begin{array}{l}\text { The Italian Health System and the COVID-19 } \\
\text { Challenge. }\end{array}$ & Armocida, B et al & $05 / 20$ \\
\hline & COVID-19 and Italy: what next? & $\begin{array}{l}\text { Remuzzi, A; Remuzzi, } \\
\text { G }\end{array}$ & $03 / 20$ \\
\hline & $\begin{array}{l}\text { Practicing Corona - towards a research agenda of } \\
\text { health policies }\end{array}$ & Bal, Ret al. & $05 / 20$ \\
\hline & $\begin{array}{l}\text { How comparable is COVID-19 mortality across } \\
\text { countries? }\end{array}$ & $\begin{array}{l}\text { Karanikolos, M; } \\
\text { Mckee, M }\end{array}$ & $06 / 20$ \\
\hline & $\begin{array}{l}\text { COVID-19 in Italy: Impact of containment measures } \\
\text { and prevalence estimates of infection in the general } \\
\text { population }\end{array}$ & $\begin{array}{l}\text { Signorelli, C.; } \\
\text { Scognamiglio, T.; } \\
\text { Odone, A }\end{array}$ & $04 / 20$ \\
\hline
\end{tabular}

Source: search data.

The actions of the health systems of the two countries to cope with the pandemic by COVID-19, presented in the publications, were grouped into five thematic categories, which will be presented below. 


\section{Adequacy of the legal norm of the health system}

To cope with the pandemic by COVID-19, changes and adaptations of the legal norm of the health system were developed. We highlight the actions of authorization of the qualification, inclusion of beds and procedures in the table of the health system to support patients with COVID-19 (BRAZIL, 2020b, 2020c, 2020d, 2020e, 2020f).

The amendments to the ANVISA regulations on the prior authorization for the export of raw materials, semi-prepared products, bulk products or finished pharmaceutical products intended to combat COVID-19 are pointed out, which had successive changes and authorization, on a temporary and exceptional basis, of the use of "rapid tests" for the diagnosis of COVID-19 in pharmacies (NATIONAL HEALTH SURVEILLANCE AGENCY, 2020a, 2020b, 2020c, 2020d).

Another legal regulation published concerns the mandatory registration of hospital admissions of suspected and confirmed cases of COVID-19, in public and private health facilities that provide services to the SUS (BRAZIL, 2020g).

From the Presidency of the Republic, there was also the publication of the Federative Program for Combating Coronavirus. This was signed by the President, his Minister of Economy and other members of the government, dealing with financial measures, including suspension of payment of debts, restructuring of credit operations and delivery of Union resources to states and municipalities, such as financial aid to cope with the pandemic (BRAZIL, 2020h).

In Italy, several standards were established in the most diverse areas and decrees were formulated with the purpose of containing the infection and increasing the protection of the Italian population, including legal adjustments made to cope with the pandemic that were adopted by the government, addressed the closure of the air border with China, when the WHO declared the emergency in public health, followed by the declaration of health emergency for a period of six months, still in January 2020. (ITALY, 2020a, 2020f, 2020g; TORRI et al., 2020).

By mid-April 2020, the Italian government enacted more than 160 decrees, orders, circular letters, notices or protocols related to COVID-19, also under the adjustment of resource allocation and testing procedures published by local regions and health authorities, updated daily, in addition to defining criteria for certain services such as blood and organ donation, in addition to a prohibition of the stay of companions in the emergency room and limitations of visits in psychiatric units and 
long-stay institutions of the elderly were also adopted. (TORRI et al., 2020; ITALY, 2020a, 2020c, 2020f, 2020g).

\section{Expansion and strengthening of the health system}

In the Brazilian context, the activation strategy of the Emergency Operations Center (EOC) of the Ministry of Health and the preparation of the contingency plan are presented as initial measures for initial preparation for the pandemic, when it was in its beginning in the global context and before the introduction in the country (OLIVEIRA et al., 2020).

With the introduction of the disease in Brazil, the measures employed were to strengthen surveillance and health care, which had the expansion of the structure for the care of severe cases; acquisition of equipment and Inputs, including mechanical fans and personal protective equipment; expansion of the number of tests for diagnosis of COVID-19; construction of hospital units; expansion of the capacity of existing units; hiring beds in hospitals in the supplementary sector and financial support to Santas Casas and philanthropic hospitals that participate in a complementary way of the SUS; support for the assembly of field hospitals and their technical criteria for implementation and operation; financial transfer to states and municipalities and guidance on the allocation of resources for the financing of actions to combat COVID-19 (OLIVEIRA et al., 2020; BRAZIL, 2020i, 2020j, 2020k, 20201).

In Italy, in addition to the health emergency declaration, on January 31, 2020, the government allocated $€ 5,000,000.00$ to the national emergency fund for the implementation of the first interventions and allocated $€ 660$ million to hire around 20,000 professionals, being 5,000 physicians with experience in intensive care, since these professionals were being more demanded to cope with the pandemic and recognizing that a large portion of physicians in the country are over 55 years of age, who together with other professionals assumed intense work routines, which associated with overcrowding of health services, were eventually affected by COVID-19, including some of which died (PALANIAPPAN; DAVE; GOSINE, 2020; DRAKE et al., 2020; ITALY, 2020a, 2020f, 2020g; REMUZZI; REMUZZI, 2020).

Also, to face the shortage of medical equipment, the Italian Civil Protection conducted an accelerated public contract to acquire 3800 respiratory ventilators, 30 million additional protective masks and 67,000 tests (ARMOCIDA; FORMENTI; USSAI, 2020). The Italian government acquired 5000 ventilators to provide 
respiratory support to critically ill patients and in regions such as Lombardy, in the face of insufficient intensive care beds, and patients who needed these beds were transferable but were not infected with COVID-19 to hospitals outside the region, to contain the spread of the virus (REMUZZI; REMUZZI, 2020).

It is worth highlighting the action developed by the Ministry of Health in Brazil, from the perspective of training human resources and expanding the coverage of the SUS to cope with the pandemic, through the registration and hiring of health professionals in the strategic action "Brazil relies on me", in addition to the launch of emergency notices of the More Doctors Program in Brazil, the latter with a view to hiring professionals to work in PHC (OLIVEIRA et al., 2020; FARIAS et al., 2020; BRAZIL, 2020m, 2020n).

There was the establishment of Community Reference Centers to cope with the pandemic, aiming to serve the general population of territories, enabling their articulation with PHC or development in its scope, as well as highlighting its structuring in areas of communities and slums, including the temporary accreditation of Brazilian municipalities and receipt of financial incentives (BRAZIL, 2020o, 2020p, 2020q).

The "Covid-19 Clinical Management Protocol in Primary Care" and strategies adopted by local health services were made available, such as the cancellation of non-essential elective consultations, scheduling by schedule, setting up outdoor clinics and protecting health professionals in risk groups (FARIAS et al., 2020).

This situation is also pointed out in the Italian context, in which non-urgent elective consultations and procedures were cancelled, maintaining only essential programs, as well as the need for joint integrated response with primary care teams for the detection, evaluation and active surveillance of suspected or confirmed cases of COVID-19 (TORRI et al., 2020; DRAKE et al., 2020).

To address the pandemic in Brazil, we highlight the promotion of research, innovation and development through support for research projects on COVID-19, in partnership with the National Council for Scientific and Technological Development (CNPq); support for research considered priority, with the collaboration of research institutions and philanthropic hospitals participating in the Program for Institutional Development of the Unified Health System (PROADI-SUS) - COVID-Brazil Coalition (OLIVEIRA, et al., 2020). 
Another publication found dealt with the installation of the Crisis Committee for planning, coordination, execution, supervision and monitoring of the impacts of COVID-19 on the health of indigenous peoples in Brazil (BRAZIL, 2020r).

\section{Encouraging individual and collective measures to cope with the pandemic}

Brazilian measures to guide the prevention of coronavirus transmission to the population and the use of containment or mitigation strategies are emphasized, depending on the behavior of the pandemic (OLIVEIRA et al., 2020); institution of the social isolation protocol (FARIAS et al., 2020); protection of the elderly as a priority strategy, guiding them to stay at home whenever possible, restrict their travel to carry out strictly necessary activities, avoid the use of means of public transport and not frequent places with agglomerations, since, for this group, quarantine is, in some cases, carried out partially because of the flow of people at home (OLIVEIRA et al., 2020; LIMA et al., 2020).

The Italian reality also highlights as a fundamental practical measure the advice to vulnerable groups, including in these elderly, in addition to the removal from work of those professionals with respiratory symptoms (TORRI et al., 2020).

Brazilian actions and strategies were reinforced through publication aimed at the prevention, control and mitigation of the transmission of the disease, in addition to promoting the physical and mental health of the population, contributing to the actions for the safe resumption of activities and safe social interaction (BRAZIL, 2020s).

Italy intensified control actions at airports and ports with body temperature verification and banned flights from China, however, such measures had no significant effect on containing the epidemic, since, at the outset, the actions were directed to isolate infected patients and create delimited red areas (SIGNORELLI; SCOGNAMIGLIO; ODONE, 2020).

Other practical measures adopted were managed by the Italian prevention departments, including mandatory supervised quarantine for 14 days for contacts of cases of the disease; mandatory communication to the Department of prevention of people coming from areas at high risk of COVID-19; surveillance, risk assessment, information and education actions for the population and professionals; closing of municipalities and suspension of events or operation of public facilities (schools, 
academies, public places); measures of social distancing; limitation of the movement of persons, unless motivated by proven work needs or health situation; suspension of commercial activities, with the exception of essential ones (TORRI et al., 2020; LA MARCA et al., 2020); recommendations for remote work and payment of holidays to employees (ITALY, 2020b).

The Italian government has adopted a total blockade throughout the country, in the hope of containing COVID-19 and preventing further dissemination, which has faced resistance from Italian citizens, particularly prisoners (PALANIAPPAN; DAVE; GOSINE, 2020), since isolation measures were instituted in the prison system for new symptomatic inmates (ITALY, 2020c).

Italy has banned the movement of people between municipalities by public or private transport, except in proven health and work situations (ITALY, 2020b). For entry into the country, documents clarifying the reasons, address of the quarantine and means of transport that would use to reach him, as well as telephone contact (ITALY, 2020e) should be presented.

Another Italian strategy was the implementation of a screening system to determine in which patients to use their limited intensive care resources (PALANIAPPAN; DAVE; GOSINE, 2020) and in hospital palliative care institutions. It was highlighted the lack of uniformity in actions such as the mandatory use of EPIs, rules of visits and follow-up of patients, in addition to admission and discharge criteria that were defined by the institutions themselves, also highlighting the strategy implemented in an institution in making daily calls to relatives who were prevented from visiting internal patients (COSTANTINI et al., 2020).

In this review, guidelines of radiology services for the non-use of chest tomography as a form of screening of patients with COVID19 were also highlighted, except for symptomatic patients with specific clinical indications, however, recommending chest X-ray as a tool for evaluating patients in the emergency room, in addition to the use of ultrasound of the lungs for monitoring and evaluating the efficacy of supination maneuvers in dorsal decubus (NERI et al., 2020).

The review did not point to the process of easing social isolation measures implemented by the two countries. Due to the situation that the pandemic was in these countries at the time of the studies and publications of ordinances and regulations. 


\section{Use of Information and Communication Technologies}

The pandemic by COVID-19 is the first major crisis in times of mediatization and more intense use of information and communication technologies, so that this influences the action of people and even in the development of public policies, a striking example was the Italian reality revealed worldwide with stacked coffins and health professionals pointing out the difficult choices they needed to make in the daily care of patients. (BAL et al, 2020).

Among the results included in the review, transparency in the publication of information and communication with the population and the press through the publication of epidemiological bulletins and collective interviews were strategies adopted in Brazil (OLIVEIRA et al., 2020).

Simultaneously, ICT tools were used to create a SRAG/ICU Covid-19 Bed Qualification Monitoring panel in the national territory, which allows managers and technical teams to monitor the number of ICU-Covid beds enabled in their state and the resources available (BRASIL, 2020t).

For the access of the population to the health system, remotely, there was the availability of new means for care, such as the Coronavirus-SUS application and the channel by WhatsApp; use of telemedicine; TeleSUS initiative (OLIVEIRA et al., 2020), this being operationalized by restraining restrictions prior to the use of telehealth and opening new opportunities for its further consolidation as a tool to improve the SUS, as from the publication of Law n. 13,989/2020, a regulatory framework defined for telemedicine in the country during the pandemic (CAETANO et al., 2020).

In Italy, publications reveal the possibility of implementing telemedicine for outpatient consultations, as well as visits by external companies or employees to be suspended and carried out through telecommunications (TORRI et al., 2020; LA MARCA et al., 2020); implementation of a telephone screening service to assess the risk of contamination by COVID-19 in patients requiring hospitalization in palliative care institutions (CONSTANTINI et al., 2020) and the use of telephony to control the evolution of people under surveillance who remained in home isolation (ITALY, 2020c) was highlighted.

Also in this direction, there was the stimulus, in Brazil, to the creation of $\mathrm{x}$-ray imaging banks and chest CT of patients from COVID-19, harmonized with 
international experience, accessed remotely to assist in the care of cases (CAETANO et al., 2020). In Italy, there has been support for research for the use of artificial technology in the radiological system of decision support in covid-19 positive patients, and the use of artificial intelligence for screening or first-line tests for the diagnosis of COVID-19 as a replacement for laboratory diagnosis (NERI et al., 2020) has not yet been indicated.

\section{Limitations and challenges in coping with the pandemic}

Brazil has little experience with disasters and calamities, and there is no local culture of prevention of these situations (LIMA et al., 2020). The President of the country presented negative approaches to the epidemic and the disputes between it and state governments in the adoption of measures such as social distancing reveal a lack of unity on the subject in the country (GREER et al., 2020). The replacement of the Brazilian Minister of Health by a military officer more aligned with the preferences of the president, who begins to disclose drugs such as hydroxychloroquine as a cure, and the attempt to reduce the leadership of state governments were other difficulties pointed out in the literature (GREER et al., 2020).

The literature highlighted the influence of the Italian political context, since at the end of February, its representatives joined the public handshake in Milan, showing that the virus did not matter, that people did not need to panic and that COVID-19 would not affect the economy and, even in the initial phase, scientists already warned of the possibility of an outbreak was not followed in the formulation of public policies. (PISANO; SADUN; ZANINI, 2020)

In Italy, limitations in adopting a more reactive approach to prevent the spread of the virus associated with the non-implementation of proactive measures to combat COVID-19 resulted in more than 2,000 deaths from the infection (PALANIAPPAN; DAVE; GOSINE, 2020), highlighting inadequate preparedness for public health emergencies, including low laboratory capacity and scarce availability of intelligent technologies to support contact tracking (TORRI et al., 2020) in addition to emphasizing that the capacity of the health system had a modest number of ICU beds and few sub-intensive care beds, totaling 5,090 ICU beds (8.4 per 100,000 inhabitants) (BOCCIA; RICCIARDI; IOANNIDIS, 2020)

The population testing policy for COVID-19 in Italy was limited, which needed to be directed to specific population groups (especially those of greater severity), a fact 
that may have contributed to reduce even reports of deaths from the disease, restricting them to cases of those who were hospitalized. (KARANIKOLOS; MCKEE, 2020).

In containing the progress of COVID-19, Italy presented weaknesses in community work, intensive screening and quarantine of contacts, representing an excessive focus on symptomatic people, as well as organizational and technological constraints during the peak of the epidemic, a factor that may have delayed the public health response, from insufficient integration and support between hospital and community primary care services, aggravating the pandemic in regions such as Lombardy (TORRI et al., 2020), in addition to apparently, patients with modest symptoms were hospitalized, limiting the reserves of vacancies when severe cases began to be admitted, which generated overcrowding of hospitals. (BOCCIA; RICCIARDI; IOANNIDIS, 2020).

Italian intensive care health professionals, due to overcrowding of services and the scarce resources available in terms of ventilatory support, had the need to deny health care, prioritizing patients who would be more likely to survive, which placed them on the one hand as modern heroes in a field of an unexpected war and on the other as targets of criticism even by the Italian bioethics committee, which recognizes that all individuals according to the constitution of the country, have the right to receive all the necessary health care for their health. (REMUZZI; REMUZZI, 2020)

\section{Discussion}

The actions and strategies adopted by the health systems of Brazil and Italy to cope with the pandemic mostly follow the world scenario and guidelines of who and PAHO, however, it is perceived that this confrontation received differentiated attention at certain times in both countries and the influences of the political and economic contexts, which are reflected in the measures adopted.

In the legal norms for Brazilian action in the face of the pandemic, the reflections of the health and political crisis experienced in Brazil are revealed. These documents were signed by at least three occupants of the post of Minister of Health, still in the first half of 2020, representing the various political clashes that have permeated the confrontation of the pandemic in this country, delineated by minimizing its effects by the President, which is sometimes not guided by 
technical and scientific criteria and ignores the individual and community measures indicated worldwide (AQUINO et al., 2020).

The measures of distancing, type of isolation, quarantine, including total blockade or lockdown, adopted in both countries, corroborate some practices developed on the world stage and that are already known historically, when facing a new disease and for which there is no validated treatment or vaccine, in addition to the impossibility of mass testing, or when health services are close to collapse, however, there are differences between the beginning of these measures in the different locations of the two countries (AQUINO et al., 2020; WERNECK; CARVALHO, 2020). Measures to make social distancing more flexible should also follow criteria such as the reduction and sustained stabilization of the number of cases and hospitalizations for the disease; a health system with sufficient capacity of beds, equipment and supplies; monitoring of the epidemic (EUROPEAN COMMISSION, 2020).

Brazil is in a scenario of polarized political disputes and interests. On the one hand, it is advocated the confrontation with the pandemic by placing public health and scientific criteria first; on the other hand, it is advocated that the country's economy may not bear the effects of the health crisis. This is a major concern, especially when finding an equally polarized population and feeling the effects of austerity policies that were already being implemented in the pre-pandemic context, which strongly affected the financing of the health and science and technology sectors in the country, weakening their capacity to respond in a timely manner (BRAZIL, 2016; DWECK, 2020).

The actions taken to suspend non-essential services, including consultations and non-urgent elective procedures, which the two countries have adopted are harmonized with guidelines from public health agencies worldwide, highlighting the stimulus and potentiality of the use of information technologies, through digital platforms for teleconsultations, information, communication and alerts to the community as an important tool to cope with the pandemic (PAN-AMERICAN HEALTH ORGANIZATION, 2020a, 2020b).

The use of information and communication technologies needs to be allied to the struggle to combat the growing network of fake news, which, more linked to denialist movements of the pandemic, end up interfering in its confrontation, this markedly seen by the mediatization in the Brazilian scenario during the evolution of the pandemic, which required the use by the Ministry of Health of a space to 
combat these pseudoinformation, through a channel through WhatsApp number, called "Health without fake news", so that doubts of the population could be sent (MERCEDES NETO et al, 2020).

The action of ANVISA releasing the performance of rapid tests in pharmacies, provided that following the standards of good practice required, as well as the communication of the results to the health authority find resonance in international recommendations, showing a way to partially fill the gap in health services in the mass testing of the population, including these services in the evaluations of production capacities and distribution of essential resources in the pandemic (PANAMERICAN HEALTH ORGANIZATION, 2020a).

The availability of EPIs for professionals, their training and the need to hire professionals to work in coping with the pandemic, the guarantee of the safety of workers from risk groups through their remanagement to lower risk activities were found in publications as an action of the two countries and are referred to in specialized literature (PAN-AMERICAN HEALTH ORGANIZATION, 2020a).

The confrontation of the pandemic reveals countriesacting, sometimes individually, closing borders and cutting relations. However, they will not leave this crisis if there is no collaboration with each other, incentives for research, appreciation of science and public health agencies at the local and international level (MORADIAN et al., 2020). Disparities within and between countries, as well as the non-valorization of measures that have proved appropriate in other realities only make the horizon of solution for this global public health emergency even more distant.

It is possible to learn from the Italian experience that precautions should be implemented in health units to protect professionals and prevent the spread of the virus. The massive use of remote technologies, such as telemedicine, minimized physical contact between professionals and users. The organization of a hospital bed management network and a well-articulated patient transport system can help in the quality of the regulatory process. The intense surveillance of people who evaluated positive and the surveillance of the social distancing of personnel and strict quarantine measures helped to reduce the peak of the epidemic in the country. (TASCA; MASSUDA, 2020).

It took a reorganization of Italy's hospital network to treat patients who were aggravated. However, we see that the articulation between the Primary Health Care Service, including the Department of Prevention, with strategic actions to 
prevent the transmission of COVID-19 and follow-up of suspected and confirmed cases has become fundamental.

The problem of this pandemic involves the strengthening of Primary Health Care (PHC). It is estimated that, on average, $80 \%$ of infected people develop mild symptoms. They can be accompanied by PHC, specifically by the Family Health Strategy Teams, with actions integrated with the Health Surveillance sector. The monitoring of suspected cases and the strengthening of health education as strategies to prevent contamination by COVID-19 are essential. Efforts have been added to increase the use of teleshealth in PHC to facilitate users' access to services and reduce the workload of professionals (HARZHEIM et al., 2020).

The extensive PHC network that Brazil has, anchored in the SUS, presents serious problems of financing, management and provision of professionals, and it is necessary to strengthen the role of PHC as an order for care in the SUS and reorganization of user flows in services in various locations (SARTI et al., 2020).

\section{Conclusion}

Although the studies point to a biomedical model centered on both countries, with efforts aimed at strengthening the hospital network, regions begin to stand out in the control of COVID-19 with actions of PHC, focusing on preventive measures, with health education and monitoring of contacts of positive cases.

Among the strategies implemented in both countries, telemedicine gained prominence, with support and resolution for a portion of the health problems of a group of people and may persist as a legacy in the post-pandemic.

The inclusion of scientific publications and official bodies helped to expand the scope of materials that portrayed the actions of coping with the pandemic by the Brazilian health system.

Legal norms, although not rescued by the search strategy adopted, were included from their description in pertinent scientific literature. This reveals the adequacy of the research protocol made for the study in question, especially when it is the Brazilian reality.

The non-inclusion of the websites of the health agencies of the two countries and the Italian virtual health library may have reduced access to the legal regulations of Italy, and left Brazilian regulations excluded from the review. However, this 
situation was minimized by pointing out the results of research articles that dealt with the strategies and actions developed within each country, as well as the expansion of the corpus of analysis related to the Italian reality with the realization of snowball sampling.

It is still too early to draw more robust assessments of the policies adopted by the two countries to cope with the pandemic by COVID19, and certainly recent studies in this direction will be prepared later.

This review will contribute as a theoretical support, by documenting the actions to combat the emergency in public health by COVID19 of the two countries, as well as to the planning of practices to contain other pandemic situations with which, eventually, their health systems may come across. It also provides to reveal the need to strengthen public health and national health systems, favoring the organized and scientifically based response to health emergencies of this magnitude.

\section{References}

AGÊNCIA NACIONAL DE VIGILÂNCIA SANITÁRIA (Brasil). Resoluçâo de Diretoria Colegiada (RDC) n. 395 de 09 de junho de 2020. Diário Oficial da União, ed. 114, seção 1, 17 jun. 2020a.

AGÊNCIA NACIONAL DE VIGILÂNCIA SANITÁRIA (Brasil). Resolução de Diretoria Colegiada (RDC) n. 371 de 15 de abril de 2020. Diário Oficial da União, seção 1, 20 mar. 2020b. AGÊNCIA NACIONAL DE VIGILÂNCIA SANITÁRIA (Brasil). Resolução de Diretoria Colegiada (RDC) n. 381, de 12 de maio de 2020. Diário Oficial da União, seção 1, 13 maio 2020c. AGÊNCIA NACIONAL DE VIGILÂNCIA SANITÁRIA (Brasil). Resolução de Diretoria Colegiada (RDC) n. 377, de 28 de abril de 2020. Diário Oficial da União, seção 1, 29 abr. 2020d.

AQUINO, Estela M. L. et al. Medidas de distanciamento social no controle da pandemia de COVID-19: potenciais impactos e desafios no Brasil. Ciênc. saúde coletiva, v. 25, 2020, supl. 1.

ARMOCIDA, B. et al. The Italian Health System and the COVID-19 Challenge. Lancet Public health, v. 5, n. 5, 2020.

BAL, R et al. Practicing Corona: towards a research agenda of health policies. Health Policy, v. 124, n. 7, p. 671-673, jul. 2020.

BOCCIA, S.; RICCIARDI, W.; IOANNIDIS, J. What other countries can learn from Italy during the COVID-19 Pandemic. JAMA Intern Med., v. 180, n. 7, p. 927-928, jul. 2020.

BRASIL. Emenda Constitucional n. 95, de 15 de dezembro de 2016. Altera o Ato das Disposiçóes Constitucionais Transitórias, para instituir o Novo Regime Fiscal, e dá outras providências. Diário Oficial da União, seção 1, 15 dez. 2016. 
BRASIL. Lei Complementar n. 173, de 27 de maio de 2020. Diário Oficial da União, ed. 101, seção 1, 28 maio $2020 \mathrm{~h}$.

BRASIL. Lei n. 13.995, de 05 de maio de 2020. Diário Oficial da União, ed. 85, seção 1, 6 maio 2020k.

BRASIL. Ministério da Saúde. Painel Coronavirus Brasil. Brasília: Ministério da Saúde, 2020a. Disponível em: https://covid.saude.gov.br/. Acesso em: 13 jul. 2020.

BRASIL. Ministério da Saúde. Portaria n. 1521, de 15 de junho de 2020. Diário Oficial da União, ed. 113, seção 1, 16 jun. 2020 b.

BRASIL. Ministério da Saúde. Portaria n. 510, de 16 de junho de 2020. Diário Oficial da União, ed. 114, seção 1, 16 jun. 2020c.

BRASIL. Ministério da Saúde. Portaria n. 245, de 24 de março de 2020. Diário Oficial da União, ed. 82, seção 1, 30 abr. 2020d.

BRASIL. Ministério da Saúde. Portaria n. 827, de 15 de abril de 2020. Diário Oficial da União, ed. 73, seção 1,16 abr. 2020 e.

BRASIL. Ministério da Saúde. Portaria n. 237, de 18 de março de 2020. Diário Oficial da União, ed. 69, seção 1, 09 abr. 2020 f.

BRASIL. Ministério da Saúde. Portaria n. 758, de 9 de abril de 2020. Diário Oficial da União, ed. 69-C, seção 1 extra, 9 abr. 2020g.

BRASIL. Ministério da Saúde. Portaria n. 430, de 19 de março de 2020. Diário Oficial da União, ed. 55, seção 1, 20 mar. 2020 i.

BRASIL. Ministério da Saúde. Portaria n. 545, de 25 de março de 2020. Diário Oficial da União, ed. 59, seção 1, 26 mar. 2020j.

BRASIL. Ministério da Saúde. Portaria n. 1514, de 15 de junho de 2020. Diário Oficial da União, ed. 113, seção 1, 16 jun. 20201.

BRASIL. Ministério da Saúde. Portaria n. 580, de 27 de março de 2020. Diário Oficial da União, ed. 61, seção 1, 30 mar. 2020m.

BRASIL. Ministério da Saúde. Portaria n. 639, de 31 de março de 2020. Diário Oficial da União, ed. 64, seção 1, 02 abr. 2020n.

BRASIL. Ministério da Saúde. Portaria n. 1444, de 29 de maio de 2020. Diário Oficial da União, ed. 103, seção 1, 1 jun. 2020o.

BRASIL. Ministério da Saúde. Portaria n. 1445, de 29 de maio de 2020. Diário Oficial da União, ed. 103, seção 1, 1 jun. 2020p.

BRASIL. Ministério da Saúde. Portaria n. 1579, de 19 de junho de 2020. Diário Oficial da União, ed. 117, seção 1, 22 jun. 2020q. 
BRASIL. Ministério da Saúde. Portaria SESAIn. 16, de 24 de março de 2020. Diário Oficial da União, seção 1, 26 mar. 2020r.

BRASIL. Ministério da Saúde. Portaria n. 1565, de 18 de junho de 2020. Diário Oficial da União, ed. 116, seção 1, 19 jun. 2020s.

BRASIL. Ministério da Saúde. Conselho Nacional de Secretários de Saúde (NCHS). Painel de Monitoramento de Habilitaçôes de Leitos SRAG/UTI Covid-19. 2020t.

BUCCIARDINI, R. et al. The health equity in all policies (HEiAP) approach before and beyond the Covid-19 pandemic in the Italian context. Int J Equity Health, v. 19, n. 1, 2020.

CAETANO, R. et al. Desafios e oportunidades para telessaúde em tempos da pandemia pela COVID-19: uma reflexão sobre os espaços e iniciativas no contexto brasileiro. Cad. Saúde Pública, v. 36, n. 5, 2020.

CONSELHO NACIONAL DE SAÚDE. Resolução n. 466, de 12 de dezembro de 2012. 2012. Disponível em: https://bvsms.saude.gov.br/bvs/saudelegis/cns/2013/res0466_12_12_2012. htm. Acesso em: 17 jul. 2020.

COSTANTINI, M. et al. Response and role of palliative care during the COVID-19 pandemic: A national telephone survey of hospices in Italy. Palliative medicine, v. 34, n. 7, p. 889-895, 2020.

DRAKE, Daniel H. et al. Echocardiography in Pandemic: Front-Line Perspective, Expanding Role of Ultrasound, and Ethics of Resource Allocation. Journal of the American Society of Echocardiography, v. 33, n. 6, p. 683-689, jun. 2020.

DWECK, E. Austeridade é a maior aliada do coronavirus no Brasil. 2020. Disponível em: http://cebes.org.br/2020/03/austeridade-e-a-maior-aliada-do-coronavirus-no-brasil. Acesso em: 1 jul. 2020.

EUROPEAN COMISSION. A European roadmap to lifting coronavirus containment measures. [2020]. Disponível em: ec.europa.eu/info/live-work-travel-eu/health/coronavirus-response/ european-roadmap-lifting-coronavirus-containment-measures_en. Acesso em: 04 nov. 2020.

FARIAS, Luis A. B. G. et al. O papel da atenção primária no combate ao Covid-19: impacto na saúde pública e perspectivas futuras. Rev. Bras. Med Fam. Comunidade, v. 15, n. 42, p. 1-8, maio, 2020.

FRATER, Jonh L. et al. COVID-19 and the clinical hematology laboratory. Am J Hematol., $v$. 42, p. 11-18, abr. 220. Supl. 1. Disponível em: https://onlinelibrary.wiley.com/doi/epdf/10.1111/ ijlh.13229. Acesso em: 20 abr. 2020.

GREER, Scott L. et al. The comparative politics of COVID-19: The need to understand government responses. Global Public Health, p. 1-4, jun. 2020. 
HARZHEIM, E. et al. Açóes federais para apoio e fortalecimento local no combate ao COVID-19: a Atenção Primária à Saúde (APS) no assento do condutor. Ciênc. saúde coletiva, v. 25 , n. 6 , jun. 2020 .

ITALY. Presidente del consiglio dei ministri. Decreto n. 26 del 01 febbraio 2020. Dichiarazione dello stato di emergenza in conseguenza del rischio sanitario connesso all'insorgenza di patologie derivanti da agenti virali trasmissibili. (20A00737). 2020a. Disponível em https:// www.trovanorme.salute.gov.it/norme/dettaglioAtto?id=73624. Acesso em: 14 out. 2020.

ITALY. Presidente del consiglio dei ministri. Decreto n. 45 del 23 febbraio 2020. Disposizioni Attuative del Decreto-Legge 23 Febbraio 2020, n. 6, Recante Misure Urgenti in Materia di Contenimento e Gestione Dell'emergenza Epidemiologica da COVID-19. (20A01228). 2020b. Disponível em: www.trovanorme.salute.gov.it/norme/dettaglioAtto?id=73196\&articolo=6. Acesso em: 30 out. 2020.

ITALY. Presidente del consiglio dei ministri. Decreto n. 59 del 08 marzo 2020. Ulteriori disposizioni attuative del decreto-legge 23 febbraio 2020, n. 6, recante misure urgenti in materia di contenimento e gestione dell'emergenza epidemiologica da COVID-19. (20A01522). 2020c. Disponível em: /www.trovanorme.salute.gov.it/norme/dettaglioAtto?id=73594. Acesso em: 30 out. 2020 .

ITALY. Presidente del consiglio dei ministri. Decreto n. 76 del 22 marzo 2020. Ulteriori disposizioni attuative del decreto-legge 23 febbraio 2020, n. 6, recante misure urgenti in materia di contenimento e gestione dell'emergenza epidemiologica da COVID-19, applicabili sull'intero territorio nazionale. (20A01807). 2020d. Disponível em: www.trovanorme.salute. gov.it/norme/dettaglioAtto?id=73729. Acesso em: 30 out. 2020.

ITALY. Presidente del consiglio dei ministri. Decreto n. 97 del 11 aprile 2020. Ulteriori disposizioni attuative del decreto-legge 25 marzo 2020, n. 19, recante misure urgenti per fronteggiare l'emergenza epidemiologica da COVID-19, applicabili sull'intero territorio nazionale. (20A02179). 2020e. Disponível em: www.trovanorme.salute.gov.it/norme/ dettaglioAtto?id=73838. Acesso em: 30 out. 2020.

ITALY. Ministero della Salute. Centro Sazonale de Sangue. DGPRE 3021 del 31 gennaio 2020. 2020f. Disponível em: https://www.trovanorme.salute.gov.it/norme/renderNormsanPdf?anno= 2020\&codLeg=73093\&parte=1\%20\&serie=null. Acesso em: 14 out. 2020.

ITALY. Ministero della Salute. Centro Nazionale de Trapianti. Prot. 429 CNT 2020. 2020g. Disponível em: www.trovanorme.salute.gov.it/norme/renderNormsanPdf?anno=2020\&codLe g=73189\&parte=1\%20\&serie=null. Acesso em: 14 out. 2020.

KARANIKOLOS, M; MCKEE, M. How comparable is COVID-19 mortality across countries? 04 jul. 2020. Disponível em: analysis.covid19healthsystem.org/index.php/2020/06/04/howcomparable-is-covid-19-mortality-across-countries. Acesso em: 14 out. 2020. 
LA MARCA, A. et al. COVID-19: lessons from the Italian reproductive medical experience. Fertility and sterility, v. 113, n. 5, p. 920-922, 2020.

LIMA, Danilo L. F. et al. COVID-19 no estado do Ceará, Brasil: comportamentos e crenças na chegada da pandemia. Ciênc. saúde coletiva, v. 25, n. 5, maio, 2020.

MARTINO, A. et al. Modelo assistencial da casa da saúde: reestruturando o cuidado na atenção primária na Itália. Saúde em Redes, v. 1, n. 3, 2015.

MERCEDES NETO et al. Fake news no cenário da pandemia de Covid-19. Cogitare enferm., v. 25, e72627, 2020.

MORADIAN, N. et al. The urgent need for integrated science to fight COVID-19 pandemic and beyond. J Transl Med., v. 18, n. 205, maio, 2020.

MOROSINI, Márcia V. G. C.; FONSECA, Angélica F; LIMA, Luciana D. Política Nacional de Atenção Básica 2017: retrocessos e riscos para o Sistema Único de Saúde. Saúde debate, v. 42, n. 116, p. 11-24, 2018.

NERI, E. et al. Use of CT and artificial intelligence in suspected or COVID-19 positive patients: statement of the Italian Society of Medical and Interventional Radiology. La Radiologia medica, v. 125 , n. 5, p. 505-508, 2020.

OLIVEIRA, Wanderson K. et al. How Brazil can hold back COVID-19. Epidemiol. Serv. Saúde, v. 29, n. 2, abr. 2020.

ONDER, G; REZZA, G; BRUSAFERRO, S. Case-Fatality Rate and Characteristics of Patients Dying in Relation to COVID-19 in Italy. JAMA, v. 323, n. 18, p. 1775-1776, 2020.

ORGANIZAÇÃO PAN-AMERICANA DA SAÚDE. Cuidados de saúde comunitários, incluindo divulgação e campanhas, no contexto da pandemia da COVID-19. 2020a. Disponível em: https://iris.paho.org/bitstream/handle/10665.2/52393/OPASWBRACOVID-1920074_ por.pdf?sequence=1\&isAllowed=y. Acesso em: 10 jul. 2020.

ORGANIZAÇÃO PAN-AMERICANA DA SAÚDE. O potencial das tecnologias da informação de uso frequente durante a pandemia. Ficha informativa. 2020b. Disponível em: https://iris. paho.org/bitstream/handle/10665.2/52023/Factsheet-ICs_por.pdf?sequence=7\&isAllowed=y. Acesso em: 10 jul. 2020.

PALANIAPPAN, A,; DAVE, U.; GOSINE, B. Comparing South Korea and Italy's healthcare systems and initiatives to combat COVID-19. Pan American journal of public health., v. 44, e53, 2020.

PISANO, G.; SADUN, R.; ZANINI, M. Lessons from Italy's response to coronavirus. Harv. Bus. Rev. 27 mar. 2020. Disponível em: hbr.org/2020/03/lessons-from-italys-response-tocoronavirus. Acesso em: 20 out. 2020. 
REMUZZI, A; REMUZZI, G. COVID-19 and Italy: what next? Lancet., v. 395, n. 10231, p. 1225-1228, 2020.

RODRIGUEZ-MORALES A. J. et al. COVID-19 in Latin America: The implications of the first confirmed case in Brazil. Travel Med Infect Dis. 29 fev. 2020.

SARTI, Thiago D. et al. Qual o papel da Atenção Primária à Saúde diante da pandemia provocada pela COVID-19? Epidemiol. Serv. Saúde, v. 29 n. 2, abr. 2020.

SIGNORELlI, C.; SCOGNAMIGLIO, T.; ODONE, A. COVID-19 in Italy: Impact of containment measures and prevalence estimates of infection in the general population. Acta Biomed., v. 91, n. 3-s, p. 175-179, 2020.

SOUZA, M. T.; SILVA, M. D.; CARVALHO, R. Revisão integrativa: o que é e como fazer. Einstein (São Paulo), v. 8, n. 1, p. 102-106, mar. 2010. Disponível em: http://www.scielo.br/scielo. php?script=sci_arttext\&pid=S1679-45082010000100102\&lng=en. Acesso em: 17 jul. 2020.

TASCA, R.; MASSUDA, A. Estratégias para reorganização da Rede de Atenção à Saúde em resposta à Pandemia COVID-19: a experiência do Sistema de Saúde Italiano na região de Lazio. APS em Revista, v. 2, n. 1, p. 20-27, abr. 2020.

TORRI E. et al. Italian Public Health Response to the COVID-19 Pandemic: Case Report from the Field, Insights and Challenges for the Department of Prevention. Int J Environ Res Public Health., v. 17, n. 10, may 2020.

WERNECK, Guilherme L.; CARVALHO, Marília S. A pandemia de COVID-19 no Brasil: crônica de uma crise sanitária anunciada. Cad. Saúde Pública, v. 36, n. 5, maio, 2020.

WHITTEMORE, R.; KNAFL, K. The integrative review: updated methodology. J Adv Nurs., v. 52, n. 5, p. 546-553, 2005.

WORLD HEALTH ORGANIZATION. Director-General's opening remarks at the media briefing on COVID-19-11 March 2020. Geneva: WHO, 2020b. Disponível em: https://www. who.int/dg/speeches/detail/who-director-general-s-opening-remarks-at-the-media-briefing-oncovid-19---11-march-2020. Acesso em: 16 abr. 2020.

WORLD HEALTH ORGANIZATION. Director-General's statement on IHR Emergency Committee on Novel Coronavirus (2019-nCoV). Geneva: WHO, 2020a Disponível em: https:// www.who.int/news-room/detail/23-01-2020-statement-on-the-meeting-of-the-internationalhealth-regulations-(2005)-emergency-committee-regarding-the-outbreak-of-novel-coronavirus-(2019-ncov). Acesso em: 16 abr. 2020.

WORLDOMETER. Countries where COVID-19 has spread. 2020. Disponível em: https:// www.worldometers.info/coronavirus/countries-where-coronavirus-has-spread/. Acesso em: 13 jul. 2020. 


\section{Resumo}

Sistemas Nacionais de Saúde e a pandemia por COVID-19: açóes de enfrentamento do Brasil e da Itália

Objetivou-se identificar as açóes desenvolvidas pelos sistemas de saúde do Brasil e da Itália para o enfrentamento da pandemia por COVID19. Trata-se de uma revisão integrativa da literatura nas bases de dados Web of Science, Scopus, Pubmed e Biblioteca Virtual de Saúde, com adição da técnica snowball, em julho de 2020. Após a coleta, 48 publicações constituíram a amostra. As açóes dos sistemas de saúde dos dois países para o enfrentamento da pandemia foram agrupadas nas categorias: Adequação do normativo legal do sistema de saúde; Ampliação e fortalecimento do sistema de saúde; Uso das Tecnologias da Informação e Comunicação; Estímulo às medidas individuais e coletivas para enfrentamento da pandemia; e Limitaçóes e desafios no enfrentamento da pandemia. As medidas adotadas são influenciadas pelos contextos político, econômico e social. Houve a reorganização da rede hospitalar nos dois países, mas identificam-se fragilidades nas açóes preventivas desenvolvidas pela Atenção Primária à Saúde, predominando o modelo biomédico. A telemedicina destacou-se neste cenário e poderá perdurar no pós-pandemia. A sumarização das açóes subsidiará o enfrentamento de outras pandemias com que, eventualmente, os sistemas de saúde destes e de outros países possam se deparar.

Palavras-chave: Infecções por Coronavírus, Pandemias, Sistemas de Saúde, Itália, Brasil. 